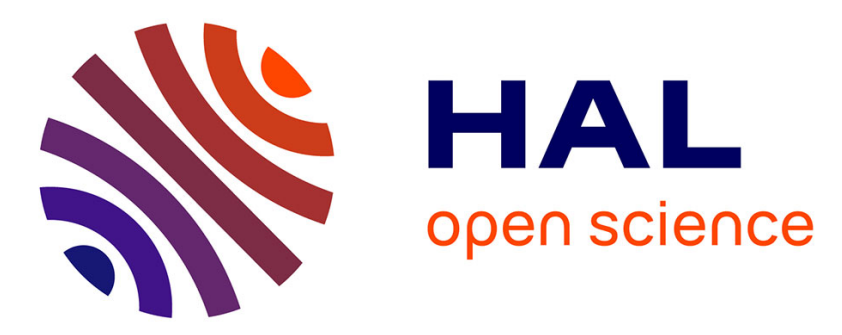

\title{
Studies towards the synthesis of secoiridoids
}

Shaoping Wu, Yongmin Zhang, Jyoti Agarwal, Emilie Mathieu, Serge

Thorimbert, Luc Dechoux

\section{To cite this version:}

Shaoping Wu, Yongmin Zhang, Jyoti Agarwal, Emilie Mathieu, Serge Thorimbert, et al.. Studies towards the synthesis of secoiridoids. Tetrahedron, 2015, 71 (40), pp.7663-7669. 10.1016/j.tet.2015.07.067 . hal-01196313

\section{HAL Id: hal-01196313 https://hal.science/hal-01196313}

Submitted on 9 Sep 2015

HAL is a multi-disciplinary open access archive for the deposit and dissemination of scientific research documents, whether they are published or not. The documents may come from teaching and research institutions in France or abroad, or from public or private research centers.
L'archive ouverte pluridisciplinaire HAL, est destinée au dépôt et à la diffusion de documents scientifiques de niveau recherche, publiés ou non, émanant des établissements d'enseignement et de recherche français ou étrangers, des laboratoires publics ou privés. 


\section{Studies towards the synthesis of secoiridoids}

Shaoping Wu ${ }^{\mathrm{a}, \mathrm{b}, \mathrm{c}}$, Yongmin Zhang ${ }^{\mathrm{a}, \mathrm{b}, \mathrm{c}}$, Jyoti Agarwal $^{\mathrm{a}, \mathrm{b}}$, Emilie Mathieu ${ }^{\mathrm{a}, \mathrm{b}}$, Serge Thorimbert ${ }^{\mathrm{a}, \mathrm{b}, *}$, Luc $\operatorname{Dechoux}^{\mathrm{a}, \mathrm{b}, *}$

${ }^{a}$ Sorbonne Universités, UPMC Univ Paris 06, Institut Parisien de Chimie Moléculaire, UMR 8232, 4 place Jussieu, F-75005 Paris, France

${ }^{\mathrm{b}}$ CNRS, UMR8232, IPCM, F-75005 Paris, France

${ }^{\mathrm{c}}$ Biomedicine Key Laboratory of Shaanxi Province, Northwest University, No. 229 Taibai North Road, Xi'an, Shaanxi 710069, PR China

*Corresponding author. Tel.: + 331442730 84; e-mail address: serge.thorimbert@upmc.fr; luc.dechoux@upmc.fr

\section{Graphical Abstract}

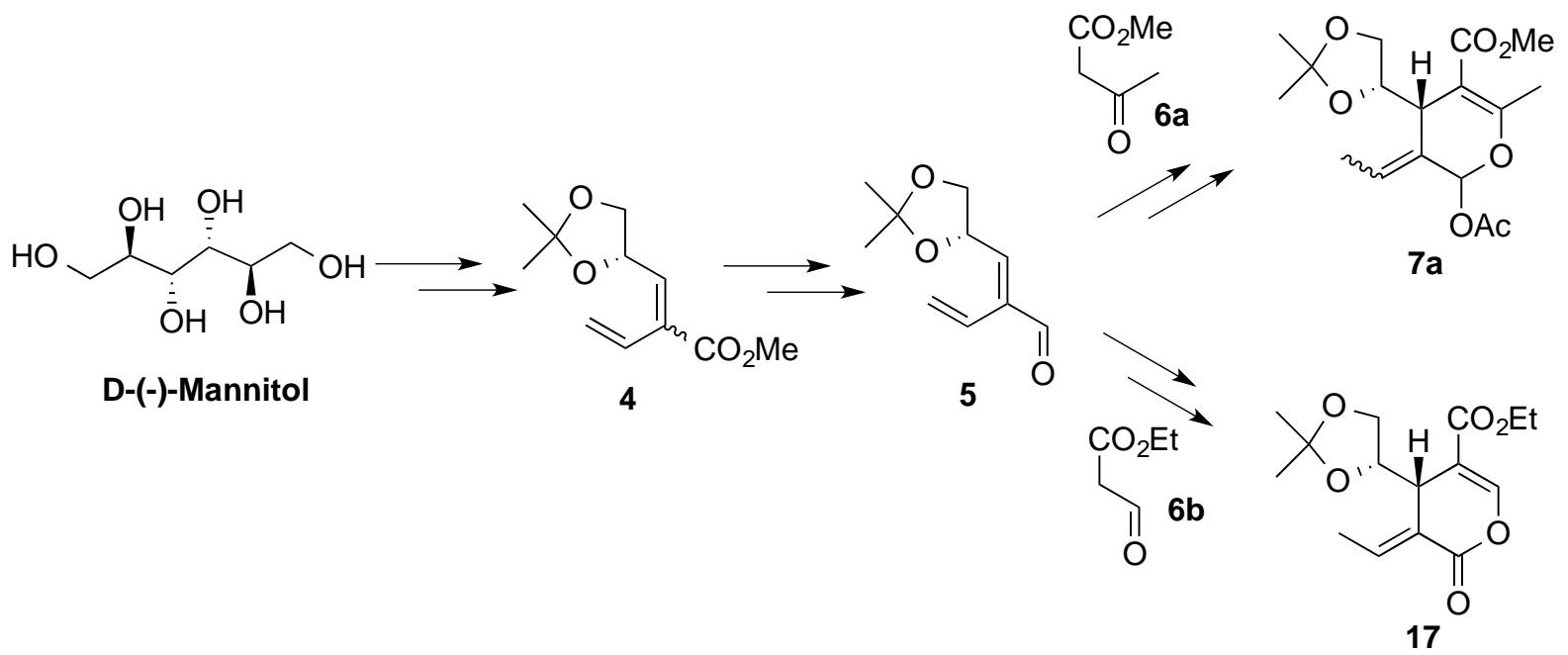

Abstract: A new approach to secoiridoids, based on the synthesis of the key functionalized intermediates $\mathbf{4}$ and $\mathbf{5}$, is presented. These compounds were tested in formal $[3+3]$ cycloadditions. Acyl-chloride 15 was transformed into enol $\alpha, \beta$-unsaturated ester 16 which was involved in a $\mathrm{N}$-Heterocyclic Carbene rearrangement to give an advanced precursor $\mathbf{1 7}$ in the total synthesis of secoiridoids

Keywords: Secoiridoids / Gentiopicroside / Organocatalysis / [3+3] Cycloadditions / NHeterocyclic-Carbenes.

\section{Introduction}

The iridoid monoterpenes represent a large family of cyclopentanopyran natural products. ${ }^{[1]}$ They usually occur as glucoside derivatives. Among them loganin is the biosynthetic precursor of secologanin, a secoiridoid playing an important role in the biosynthesis of indole alkaloids. ${ }^{[2]}$ Moreover secologanin is also a key intermediate in the biosynthesis of 
secoiridoids, such as sweroside, swertiamarin and gentiopicroside. ${ }^{[3]}$ The synthesis of this class of bioactive natural products ${ }^{[4]}$ continues to be an active area of research. Among these compounds, no total synthesis of gentiopicroside ${ }^{[5]}$ has been realized to date, and so, is still a challenge for organic chemists.<smiles>COC(=O)C1=COC(OC)[C@H]2C[C@H](O)[C@@H](C)[C@H]12</smiles>

Loganin<smiles>[CH2]OC1OC=C(C(C)=O)[C@H](CC)[C@@H]1C=C</smiles>

Secologanin<smiles>C=C[C@@H]1[C@H](OC(C)=O)OC=C2C(=O)OCC[C@@H]21</smiles>

Sweroside<smiles>C=C[C@@H]1[C@H](OC(Cl)Cl)OC=C2C(=O)OCC[C@@]21O</smiles>

Swertiamarin<smiles>C=C[C@H]1C2=CCOC(=O)C2=CO[C@@H]1OC(C)=O</smiles>

Gentiopicroside

Figure 1. Chemical structures of Loganin and selected secoiridoids.

The main strategies to the access to the 3,4-dihydropyran ring systems of iridoids or secoiridoids are depicted in Scheme 1. G. Büchi's group presented the first synthesis of an iridoid glucoside (loganin) in 1970, the first step of the synthesis was a photochemical [2+2] cycloaddition between 2-formylmalonaldehydic acid methyl ester and a cyclopentene derivative followed by a rearrangment leading to loganin aglycone via an acetalization of the transient formed $\delta$-di-aldehyde. ${ }^{[6]}$ Similarly, Grée synthesized (-)-verbenalol and (-)epiverbenalol by ozonolysis of a diquinane intermediate, which led to the formation of the iridoids. ${ }^{[7]}$ The same strategy was also used by Liao ${ }^{[8]}$ to synthesize (+/-)-forsythide. Chang ${ }^{[9]}$ synthesized secologanoside aglycone and Trost ${ }^{[10]}$ prepared loganine aglycone, respectively. In fact, R. T. Brown was the first chemist who developed this strategy (oxidation and further acetalization of $\delta$-di-aldehyde intermediates to form 3, 4-dihydropyran rings). ${ }^{[11]}$ A second strategy adopted by Tietze relied on an hetero [4+2] cycloaddition reaction as a key step for the convergent synthesis of the $( \pm)$-sweroside aglycone O-Et. ${ }^{[12]}$

The intramolecular formal [4+2] enamine-enal cycloaddition, first described by Schreiber, ${ }^{[13]}$ has been used for the entry into the iridoid carbon skeleton. He demonstrated that iridoid systems could be obtained by domino enamine Michael addition-acetalisation. MacMillan $^{[14]}$ took advantage of this strategy in the total synthesis of brasolide and littoralisone using catalytic amount of proline as organocatalyst. Using the same formal [4+2] enamine-enal cycloaddition, similar iridoid scaffolds (without the ester function) were synthesized by C. Garcia's group ${ }^{[15]}$ and J. E. Hofferberth ${ }^{[16]}$, respectively. More recently D. W. Lupton used $N$-heterocyclic carbenes to catalyze rearrangement of $\alpha$, $\beta$-unsaturated enolesters allowing the access to dihydropyranones possessing the monoterpene skeleton of the iridoid's family. ${ }^{[17]}$ 
-dialdehydes acetalization<smiles>COC(=O)C1=CO[C@@H](O)C2[C@H]1C[C@@H](O)[C@@H]2C</smiles>

Loganin aglycone (Büchi G.)

-dialdehydes acetalization

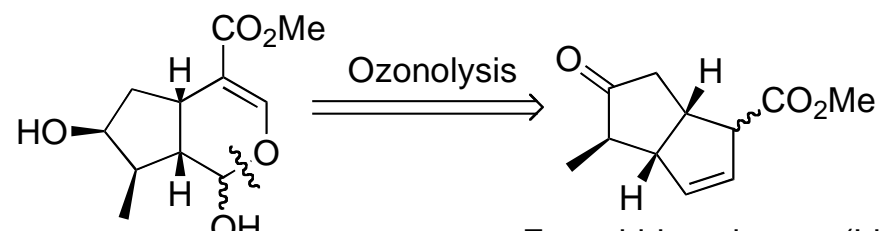

Forsythide aglycone (Liao C. C.)

Loganin aglycone (Trost B.M.)

(-)-Epiverbenalol aglycone (Grée R.)

Secologanoside aglycone (Chang N. C.)

Elenolide (Brown R. T.)

[4+2] cycloaddition<smiles>C=C/C=C1/C(=O)OCC[C@@H]1[C@H](C=C)OC</smiles><smiles>CCO/C=C\CCS(=O)(=O)CC/C=C(/C)C=O</smiles>

Sweroside aglycone (Tietze L. F.)

Enamine-enal formal [4+2] cycloaddition

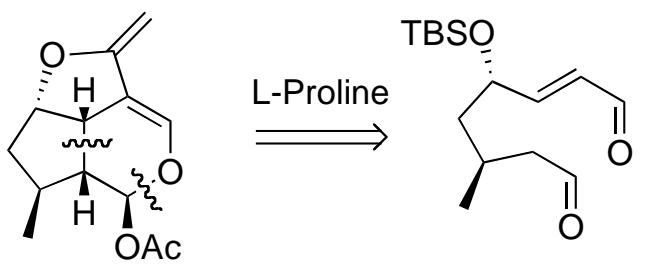

Brasoside aglycone (MacMillan W. C.)

Formal

$[3+3]$ cycloaddition

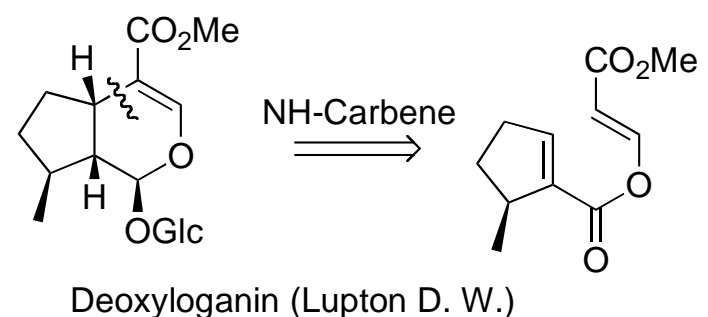

Scheme 1. Different strategies towards synthesis of iridoid or secoiridoid aglycones.

Few [3+3] cycloadditions have been described but only between activated $\beta$-diketones (coumarin derivatives) ${ }^{[18]}$ or unsaturated $\beta$-ketoesters ${ }^{[19]}$ with unsaturated aldehydes under organocatalysis (with proline derivatives). In contrast non-activated $\beta$-diketones or $\beta$ ketoesters reacted with unsaturated aldehydes to give cyclopentanones ${ }^{[20]}$ and cyclohexenones, ${ }^{[21]}$ respectively. To the best of our knowledge no formal direct $[3+3]$ 
cycloaddition between two aldehydes $\left(\mathrm{R}_{3}=\mathrm{H}\right)$ was explored in order to get 3,4-dihydropyran scaffolds (Scheme 2).

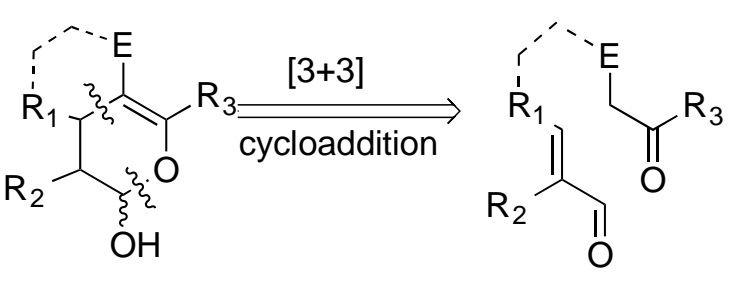

This study, $R_{3}=H, E=$ ester

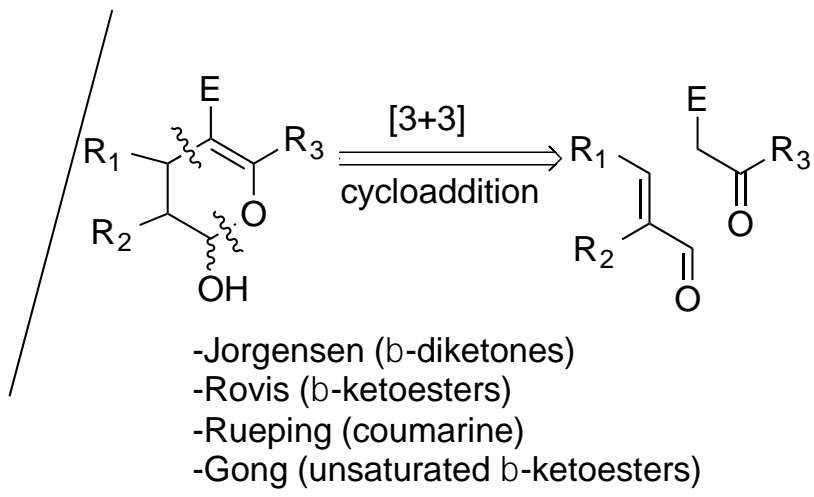

Scheme 2. [3+3] cycloaddition strategies.

At the origin of our study towards the total synthesis of gentiopicroside, we envisaged such original approaches based on an organocatalyzed intermolecular [3+3] cycloaddition between aldehyde $\mathbf{B}$ and enol ester $\mathbf{C}$ or an intramolecular [3+3] cycloaddition version from precursor D. We thought that either an intermolecular [3+3] cycloaddition or an intramolecular [3+3] cycloaddition relying on a domino enamine Michael addition acetalisation (using secondary amines as catalyst) would operate. These approaches were unfortunately inoperative. Nevertheless we wish to present here our study related to these two approaches (pathways I and II, scheme 3) and in the mean time the efficient synthesis of the $\alpha, \beta$-unsaturated ester 4 (A) and $\alpha, \beta$-unsaturated aldehyde 5 (B) which could be easily prepared in few steps from D-(-)-manitol and methylcrotonate. These compounds could be useful synthons in diverse cycloaddition processes and were finally used in the third retrosynthetic strategy (pathway III). This one is based on a $N$-heterocyclic carbene catalyzed rearrangement of $\alpha, \beta$-unsaturated enol-esters $\mathbf{E}$ (Scheme 3) which gave an advanced intermediate $\mathbf{H}$ toward the synthesis of gentiopicroside. 


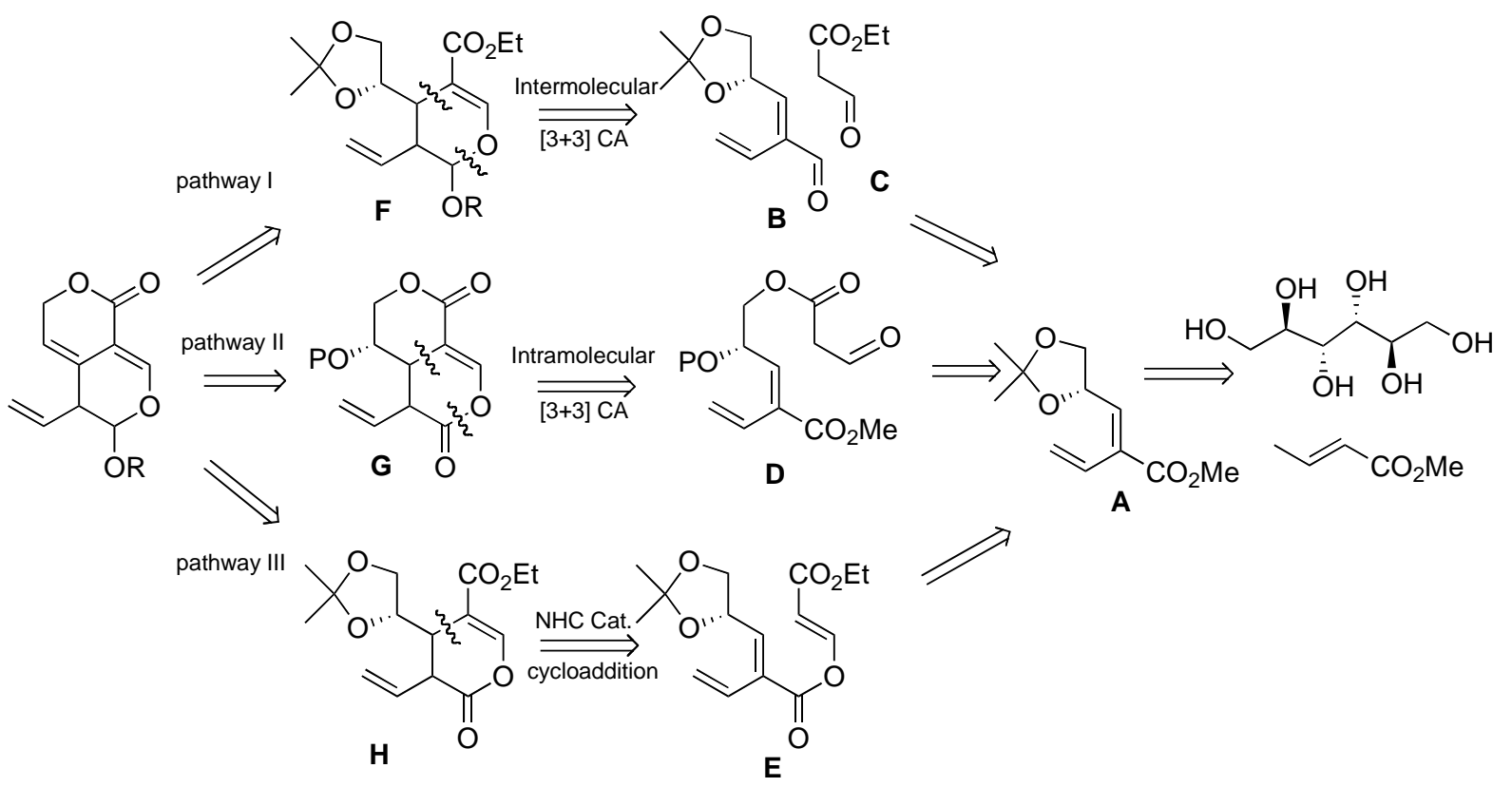

Scheme 3. Retrosynthetic analysis of gentiopicroside.

\section{Results and Discussion}

The Michael acceptor 5 was synthesized starting from D-(-)-manitol. Protection in standard conditions led to diacetonide 1 . After an oxidative cleavage, ${ }^{[22]}$ addition of methyl crotonate enolate onto the aldehyde $\mathbf{2}$ was performed. The alcohol function in $\mathbf{3}$ was mesylated and eliminated to obtain the $\alpha, \beta$-unsaturated ester 4 with a 3:2 E:Z ratio (established by NOESY). However, slow change in the diastereomeric ratio from 3:2 to 8:2 was observed in favor of $E$ isomer over some days even at $0{ }^{\circ} \mathrm{C}$. Finally the ester function of the mixture of both diastereoisomers was reduced to alcohol using DIBAL-H then oxidized to afford aldehyde 5. ${ }^{[23]}$ Oxidation using $\mathrm{PCC},{ }^{[24]} \mathrm{MnO}_{2}{ }^{[25]}$ or Dess-Martin conditions ${ }^{[26]}$ gave the desired aldehyde 5 in less then $20 \%$ yield whereas Parikh-Doering conditions gave the desired aldehyde $\mathbf{5}$ in $81 \%$ yields over two steps. ${ }^{[23]}$ The Michael acceptor $\mathbf{5}$ was thus obtained on a gram scale (> $5 \mathrm{~g}$ ) stereoselectively as the thermodynamically more stable $E$ isomer in $34 \%$ overall yield from D-(-)-manitol (Scheme 4). 


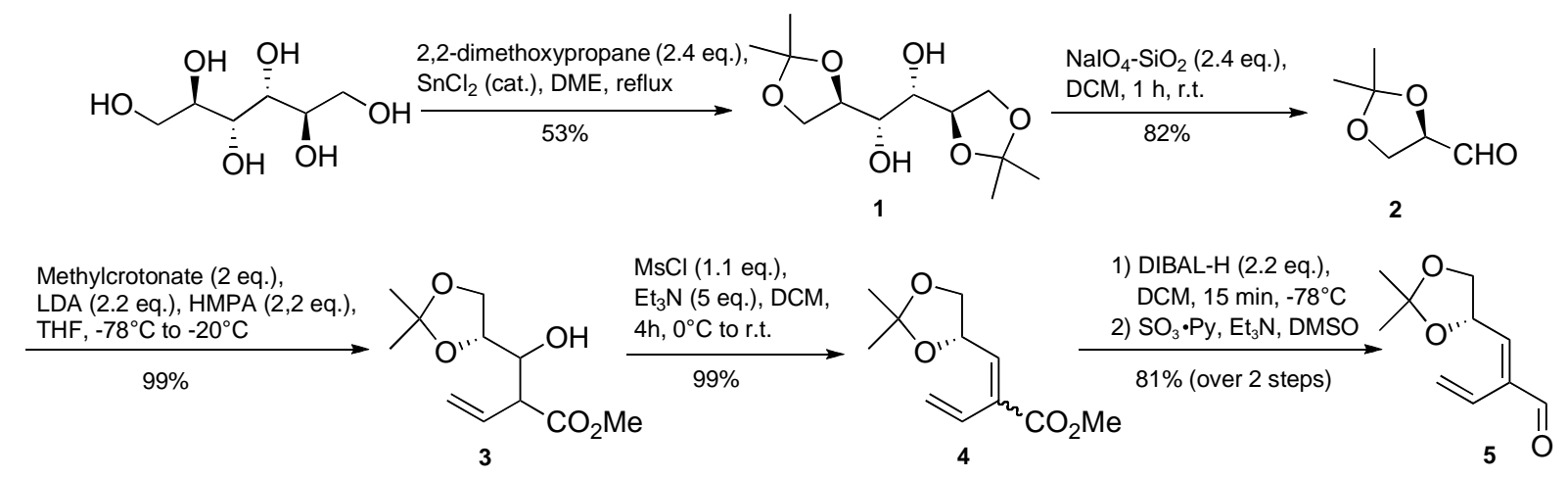

Scheme 4. Synthesis of the Michael acceptor 5.

In order to investigate the best conditions for the formal intermolecular $[3+3]$ cycloaddition, reactions between aldehyde $\mathbf{5}$ and methylacetoacetate $\mathbf{6 a}$ or the aldehyde-ester 6b as partners were tested using four different secondary amines derived from proline as catalyst ( $L$-proline, $(S)$-prolinol, $(S)$-t-butylester proline, $(S)$-diaryl prolinol trimethylsilyl ether $^{[27]}$ (Scheme 5).

With methylacetoacetate $\mathbf{6 a}\left(\mathrm{R}_{1}=\mathrm{Me}\right)$ as Michael donor, the combination of benzoic acid and diaryl prolinol trimethylsilyl ether $\mathbf{8}$ as catalyst allowed, after acetylation of the transient hemi-acetal, the formation of dihydropyran $7 \mathbf{a}$.
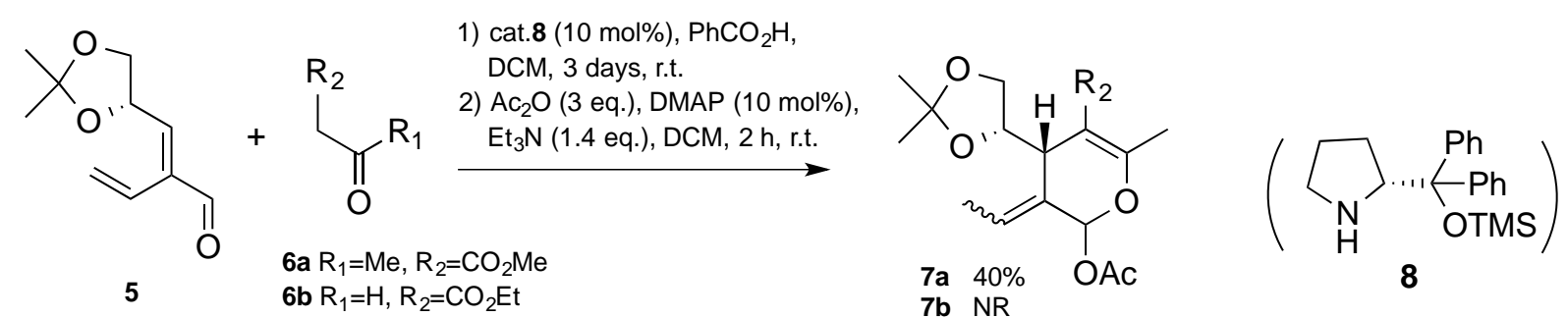

Scheme 5. Formal [3+3] cycloaddition with $\beta$-ketoester.

This [3+3] cycloaddition worked moderately and the product $7 \mathbf{a}$ was isolated as a mixture of two diastereoisomers in $40 \%$ yield. The observed high stereoselectivity (d.r. > 90/10) in favor of syn product could be explained by a cooperative effect between a Felkin control ${ }^{[28]}$ and the chiral $(R)$-organocatalyst. ${ }^{[27]}$ The relative configuration of the double bond was not unambiguously determined on each isomer. We observed the migration of the vinylic double bond, which could be explained by the protonation of the intermediate enamine at the delta carbon (Scheme 6). 


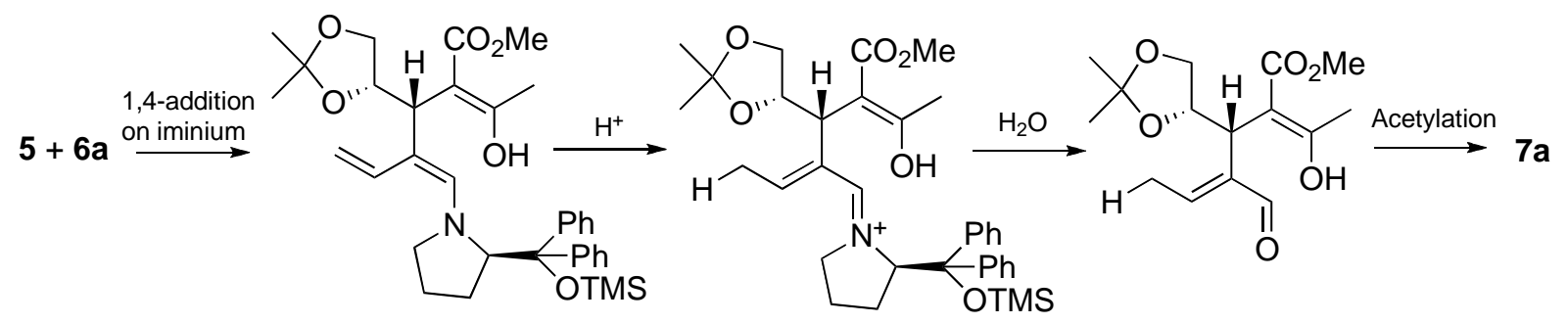

Scheme 6. Proposed mechanism for the vinyl migration.

In spite of the moderate yield obtained in the model reaction with crotonaldehyde $\mathbf{6 a}$, we explored the reaction with the aldehyde-ester 6b. Unfortunately, no traces of 3,4dihydropyran compound (F, pathway I, Scheme 3) could be detected in the crude reaction mixture. At this stage we concluded that the organocatalyzed reaction, for the formal $[3+3]$ cycloaddition between the two aldehydes $\mathbf{5}$ and $\mathbf{6 b}$ did not work. The normal course of the reaction, that is the formation of the unsaturated iminium from enal $\mathbf{5}$, is overwhelmed by the formation of $Z$-enamines from the condensation of aldehyde $\mathbf{6 b}$ and proline derivatives. Indeed, we observed, the rapid formation of stable $Z$-enamines arising from the condensation between aldehyde $\mathbf{6 b}$ and the various catalysts.

At this stage we sought to test the feasibility of an intramolecular cycloaddition (Scheme 3, pathway II). Deprotection of acetal 4 was realized in the presence of copper chloride. ${ }^{[29]}$ The primary alcohol function of $\mathbf{9}$ reacted with formyl-Meldrum acid $\mathbf{1 0}$ to give the expected ester 11 which was unambiguously detected as a mixture of two diastereoisomers as major products in the crude. All attempts to purify $\mathbf{1 1}$ were unsuccessful. Treatment of the crude in acidic media $\left(\mathrm{NH}_{4} \mathrm{OAc}, \mathrm{TsOH}\right)^{[30]}$ or with proline gave complex reaction mixtures. In the presence of catalytic amount of MeONa in THF, the $Z$-isomer of $\mathbf{1 1}$ gave the $\gamma$-lactone $\mathbf{1 3}$ arising from intramolecular transesterification and left the $E$-isomer 11 unreacted (Scheme 7).

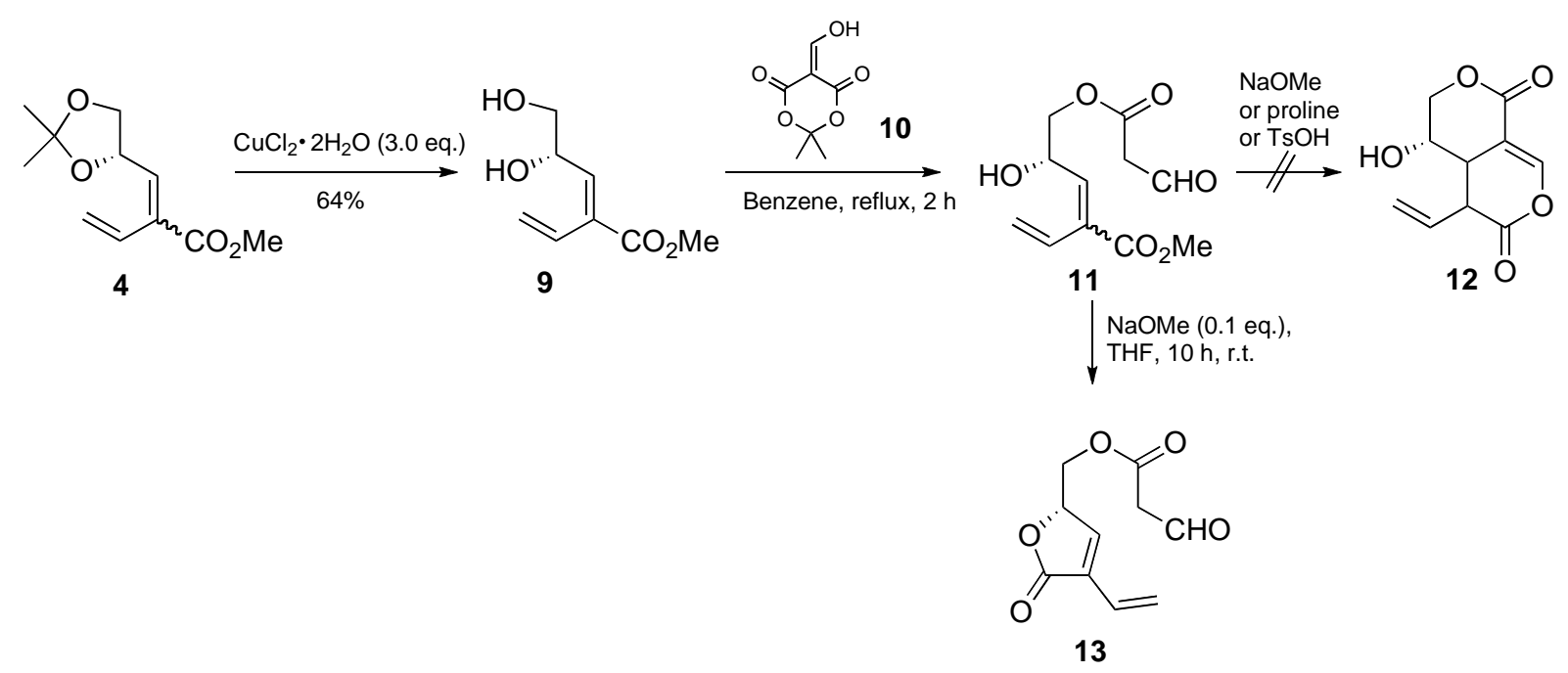

Scheme 7. Intramolecular approach towards synthesis of bicyclic lactone. 
In view of the unsuccessful precedent approaches (Scheme 3, pathway I and II), we considered the unsaturated ester $\mathbf{4}$ as a possible intermediate in the synthesis of enol-ester 16 (E in Scheme 3, pathway III). This approach was inspired by Lupton's work on similar enolesters $^{[17]}$ and could be envisaged as a formal $[3+3]$ cycloaddition if we consider the latest steps of the mechanism (scheme 9).

The synthesis began with saponification of the ester 4 with aqueous $\mathrm{LiOH}$ to provide the corresponding acid $\mathbf{1 4}$ as a 3:1 mixture of diastereoisomers (Scheme 8). The further transformation into acyl-chloride 15 was difficult and standard conditions $\left(\mathrm{SOCl}_{2}\right.$ or oxalylchloride) were unsuccessful. Eventually the used of cyanuric chloride which has been described in the literature ${ }^{[31]}$ allowed us to obtain the expected acyl-chloride $\mathbf{1 5}$ in moderate yield. It was not purified and directly engaged in the esterification of the aldehyde-ester $\mathbf{6} \mathbf{b}^{[16]}$ in the presence of Hünig's base. Some degradation of the product decreased the yield to $16 \%$ in this two steps reaction. To our delight treatment of enol-ester 16 with $\mathrm{N}$-HeterocyclicCarbene (NHC, formed by deprotonation of the pyrrolidium salt) as catalyst, provided the lactone 17 in $58 \%$ yield as a 3:2 mixture of two diastereoisomers $(E$-syn/E-anti). The $E$ configurations were determined by NOESY experiments. Concerning the low syn/anti stereoselectivity, the Felkin control which should lead to syn product seems not to be operative (see vide infra).
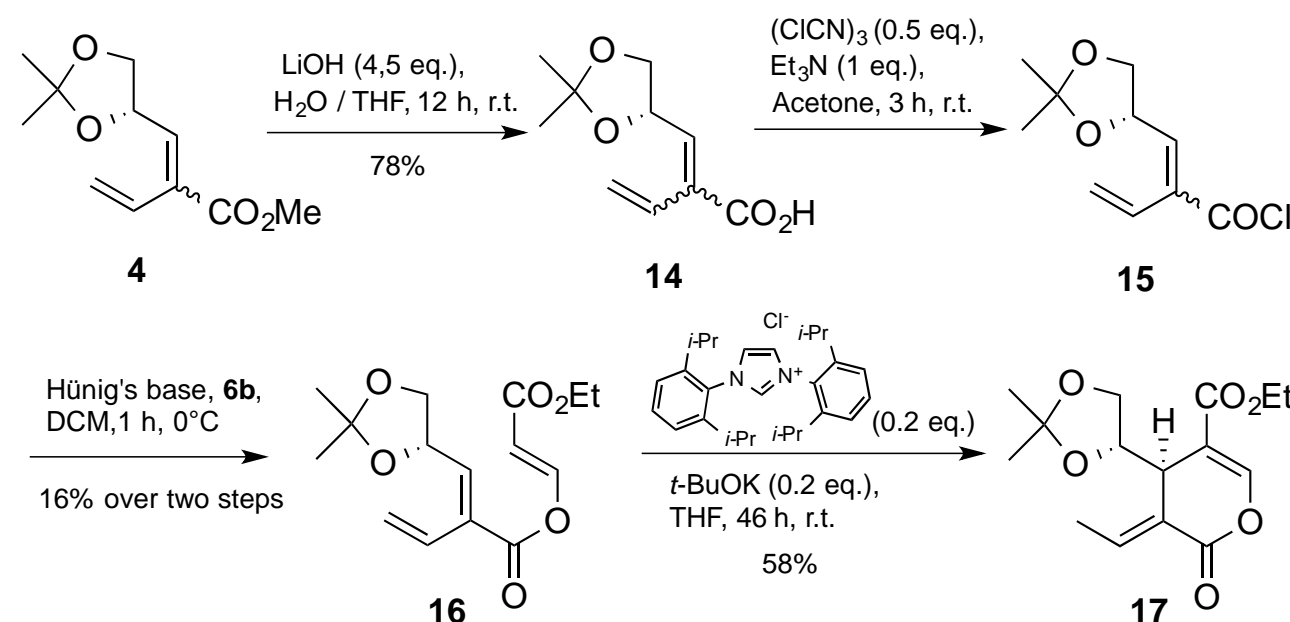

Scheme 8. NHC catalyzed strategy for the synthesis of precursor 17.

Once again the migration of the vinyl moiety was observed. We speculate that the migration of the double bond occurred after the 1,4-addition to the activated Michael 
acceptor, ${ }^{[17 e]}$ The observed total $E$-configuration arised from the protonation of conjugated enolate with intramolecular 1,5-proton transfer (Scheme 9).

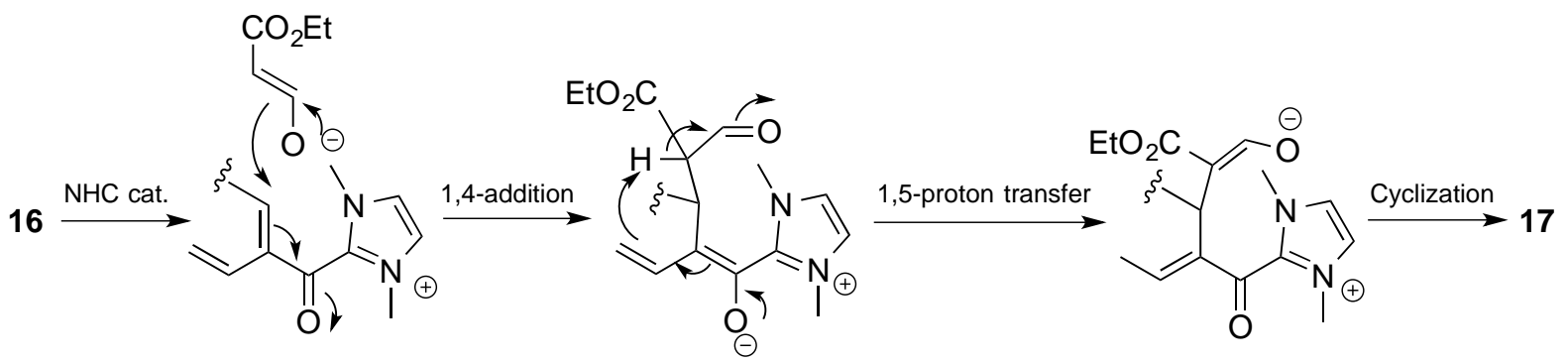

Scheme 9. Proposed mechanism for the vinyl migration.

Nevertheless, precursor 17 could eventually be used further in the synthesis of secologanin, sweroside or gentiopicroside. Actually, it requires several key steps among others, deconjugation of the latter isomerized vinyl moiety ${ }^{[32]}$ in addition to lactonisation and deoxygenation or elimination of the secondary hydroxyl function.

\section{Conclusion}

In summary, the synthesis of synthons $\mathbf{4}$ and $\mathbf{5}$ has been achieved in excellent yield and should be a valuable tool in the synthesis of secoiridoid derivatives. The formal $[3+3]$ cycloaddition between enal $\mathbf{5}$ and aldehyde $\mathbf{6 b}$ did not provide the expected cycloadduct even if on a model reaction, the 3,4-dihydropyran 7a was formed. The NHC induced rearrangement of unsaturated enol-ester $\mathbf{1 6}$ gave access to compound $\mathbf{1 7}$ that could be an advanced precursor in the synthesis of different secoiridoids as for example the challenging gentiopicroside.

\section{Experimental Section}

\subsection{General information}

All reactions were performed under nitrogen atmosphere. Reagents were all analytically or chemically pure and used without further purification unless specified. Solvents were reagent grade and, when necessary, were purified and dried by standard methods. ${ }^{1} \mathrm{H}$ NMR and ${ }^{13} \mathrm{C}$ NMR spectra were recorded on a Bruker 400 spectrometer using $\mathrm{CDCl}_{3}$ as solvent with its residual peaks as internal standard. Chemical shifts are reported in parts per million $(\delta)$, and signals are expressed as s (singlet), $\mathrm{d}$ (doublet), $\mathrm{t}$ (triplet), $\mathrm{q}$ (quartet) or $\mathrm{m}$ (multiplet). High resolution mass spectral (HRMS) analyses were taken on a Bruker micrOTOF mass 
spectrometer using electron spray ionization. Optical rotations were determined with a JASCO P-2000 polarimeter. TLC was performed on Silica Gel GF254 for TLC (Merk) and spots were visualized by irradiation with UV light $(254 \mathrm{~nm})$ or by CAM containing Cerium Sulfate $(1.0 \mathrm{~g})$ and ammonium molybdate (VI) tetrahydrate $(25.0 \mathrm{~g})$ in $10 \% \mathrm{H}_{2} \mathrm{SO}_{4}(500 \mathrm{~mL})$ followed by heating. Flash column chromatography was performed on column packed with Silica Gel 60 (200-300 mesh, Merk).

4.2. Methyl 2-((2,2-dimethyl-1,3-dioxolan-4-yl)(hydroxy)methyl)but-3-enoate (3): A 1.6 M solution of $n$-BuLi in hexane (108 mL, $173.6 \mathrm{mmol}, 2.3$ equiv) was added to a solution of di-iso-propylamine (27 mL, $197.5 \mathrm{mmol}, 2.5$ equiv) in anhydrous THF (300 mL) at $-20{ }^{\circ} \mathrm{C}$, and the resulting solution stirred for $20 \mathrm{~min}$ at same temperature. The reaction mixture was then cooled to $-78{ }^{\circ} \mathrm{C}$, HMPA (30.9 mL, $177.5 \mathrm{mmol}, 2.2$ equiv) was added, after stirring for an additional $30 \mathrm{~min}$, a solution of methyl crotonate $(16.7 \mathrm{~mL}, 157.9 \mathrm{mmol}, 2.0$ equiv) in THF $(40 \mathrm{~mL})$ was added dropwise at $-78^{\circ} \mathrm{C}$. After stirring for $5 \mathrm{~min}$, a solution of 2 (10.26 g, 78.9 mmol, 1 equiv) in THF (15 mL) was added in one portion. The mixture was allowed to reach $-20{ }^{\circ} \mathrm{C}$, then cooled again to $-70{ }^{\circ} \mathrm{C}$ and quenched with aqueous $\mathrm{NH}_{4} \mathrm{Cl}(320 \mathrm{~mL})$. The organic layers were extracted with dichloromethane $(3 \times 200 \mathrm{~mL})$, dried over $\mathrm{MgSO}_{4}$, filtered and evaporated to obtain crude product. Flash column chromatography was performed (Ethyl Acetate/Cyclohexane $25 / 75 \rightarrow 35 / 65$ ). Finally the product 3 was obtained in $99 \%$ yield as a mixture of diastereoisomers. $\mathrm{R}_{\mathrm{f}}=0.53$ (Ethyl Acetate/Cyclohexane, 1:1). Major diastereoisomer: ${ }^{1} \mathrm{H}$ NMR (400 MHz, $\mathrm{CDCl}_{3}$ ): $\delta=5.95$ (ddd, $J=17.1,10.3,9.1 \mathrm{~Hz}, 1 \mathrm{H}$ ), 5.24-5.39 (m, 2 H), 3.94-4.10 (m, 4 H), 3.74 (s, 3 H), 3.38 (dd, $J=9.1,2.3 \mathrm{~Hz}, 1 \mathrm{H}), 1.40$ (s, $3 \mathrm{H}), 1.33$ (s, $3 \mathrm{H}) \mathrm{ppm} .{ }^{13} \mathrm{C} \mathrm{NMR}\left(101 \mathrm{MHz}, \mathrm{CDCl}_{3}\right): \delta=174.1,130.7,121.2,109.4,75.6$, 72.9, 67.0, 52.3, 52.0, 26.9, 25.4 ppm. HRMS (ESI): calcd. for $\mathrm{C}_{11} \mathrm{H}_{18} \mathrm{NaO}_{5}[\mathrm{M}+\mathrm{Na}]^{+}$ 253.1046; found 253.1038.

\section{3. $(Z) /(E)$-Methyl 2-((4S)-(2,2-dimethyl-1,3-dioxolan-4-yl)methylene)but-3-enoate (4):} Mesyl chloride (4 mL, $51.7 \mathrm{mmol}, 1.2$ equiv) was added slowly to a solution of $\mathbf{3}$ (10.78 $\mathrm{g}$, $46.9 \mathrm{mmol}, 1.0$ equiv) in anhydrous dichloromethane at $0{ }^{\circ} \mathrm{C}$ under argon atmosphere. Then triethylamine (34 mL, $244 \mathrm{mmol}, 5.0$ equiv) was added dropwise to the solution and precipitation occurred. The mixture was allowed to warm up to room temperature and stirred for $4 \mathrm{~h}$. The solution was quenched with water $(100 \mathrm{~mL})$ and product was extracted with dichloromethane $(3 \times 50 \mathrm{~mL})$. Combined organic layers were washed with brine, dried over $\mathrm{MgSO}_{4}$ and solvent was evaporated under reduced pressure to get the product 4 (9.94 g, 99\%) $E / Z$ ratio 3:2 (determined by ${ }^{1} \mathrm{H}$ NMR) in quantitative yield after flash column 
chromatography (Ethyl Acetate/Cyclohexane, 1:5), $\mathrm{R}_{\mathrm{f}}=0.34$ (Ethyl Acetate/Cyclohexane, 1:3). Pure diastereoisomer $E:[]_{D}^{20}=+34.4\left(\mathrm{c} 1.0, \mathrm{CHCl}_{3}\right) .{ }^{1} \mathrm{H} \mathrm{NMR}\left(400 \mathrm{MHz}, \mathrm{CDCl}_{3}\right): \delta=$ $6.61(\mathrm{~d}, J=8.4 \mathrm{~Hz}, 1 \mathrm{H}), 6.39(\mathrm{dd}, J=17.2,11.7 \mathrm{~Hz}, 1 \mathrm{H}), 5.37(\mathrm{~m}, 2 \mathrm{H}), 4.86(\mathrm{~m}, 1 \mathrm{H}), 4.07$ $(\mathrm{dd}, J=8.1,6.4 \mathrm{~Hz}, 1 \mathrm{H}), 3.71(\mathrm{~s}, 3 \mathrm{H}), 3.63(\mathrm{dd}, J=8.1,7.3 \mathrm{~Hz}, 1 \mathrm{H}), 1.39$ (s, $3 \mathrm{H}), 1.33$ (s, $3 \mathrm{H}) \mathrm{ppm} .{ }^{13} \mathrm{C}$ NMR $\left(101 \mathrm{MHz}, \mathrm{CDCl}_{3}\right): \delta=166.5,139.3,133.5,128.9,121.3,110.0,72.3$, 69.2, 52.0, 26.5, 25.6 ppm. Diatereoisomer Z: ${ }^{1} \mathrm{H}$ NMR (400 MHz, $\left.\mathrm{CDCl}_{3}\right): \delta=6.35(\mathrm{dd}, J=$ $17.2,11.0 \mathrm{~Hz}, 1 \mathrm{H}), 6.11(\mathrm{~d}, J=6.9 \mathrm{~Hz}, 1 \mathrm{H}), 5.42(\mathrm{~d}, J=17.2 \mathrm{~Hz}, 1 \mathrm{H}), 5.18(\mathrm{~d}, J=11.0 \mathrm{~Hz}$, $1 \mathrm{H}), 4.21-4.27$ (dd, J = 8.4, $6.9 \mathrm{~Hz}, 1 \mathrm{H}), 3.78$ (s, $3 \mathrm{H}), 3.62(\mathrm{dd}, J=8.4,6.9 \mathrm{~Hz}, 1 \mathrm{H}), 1.35$ $(\mathrm{s}, 3 \mathrm{H}) 1.41(\mathrm{~s}, 3 \mathrm{H}) ;{ }^{13} \mathrm{C} \mathrm{NMR}\left(101 \mathrm{MHz}, \mathrm{CDCl}_{3}\right): \delta=166.5,139.4,133.5,133.3,117.1$, 109.6, 73.9, 69.4, 51.8, 26.5, 25.4 ppm. HRMS (ESI): calcd. for $\mathrm{C}_{11} \mathrm{H}_{16} \mathrm{NaO}_{4}[\mathrm{M}+\mathrm{Na}]^{+}$ 235.0941; found 235.0933.

4.4. (E)-2-((4S)-(2,2-Dimethyl-1,3-dioxolan-4-yl)methylene)but-3-enal (5): To a solution of ester 4 (3.18 g, $15 \mathrm{mmol}, 1.0$ equiv) in anhydrous DCM $(15 \mathrm{~mL})$ at $-78{ }^{\circ} \mathrm{C}$ was added slowly DIBAL-H (1 M in hexane, $33 \mathrm{~mL}, 2.0$ equiv). The solution was stirred for $15 \mathrm{~min}$ at $78{ }^{\circ} \mathrm{C}$. The reaction was quenched with the dropwise addition of methanol until effervescence ceased. The reaction mixture was diluted with 5 volumes of diethyl ether and stirred vigorously for $1 \mathrm{~h}$ with a saturated solution of Rochelle's salt. The organic layers were separated and the aqueous layer extracted once with diethyl ether. Combined organic layers were dried over $\mathrm{MgSO}_{4}$, filtered and the solvent carefully removed under reduced pressure. The obtained alcohol (2.75 g, 99\%) was used after flash column chromatography (Ethyl Acetate/Cyclohexane, 1:6). $\mathrm{R}_{\mathrm{f}}=0.22\left(\right.$ Ethyl Acetate/Cyclohexane, 1:4). []$_{D}^{20}=-4.6$ (c 1.0, $\mathrm{CHCl}_{3}$ ). HRMS (ESI): calcd. for $\mathrm{C}_{10} \mathrm{H}_{16} \mathrm{NaO}_{3}[\mathrm{M}+\mathrm{Na}]^{+}$207.0997; found 207.0992.

To a stirred solution of alcohol (7.21 g, $39.2 \mathrm{mmol}, 1.0$ equiv) in anhydrous DCM/DMSO (2:1) were added $\mathrm{Et}_{3} \mathrm{~N}$ and sulfur trioxide pyridine complex (24.91 g, $150 \mathrm{mmol}, 4.0$ equiv) at $0{ }^{\circ} \mathrm{C}$. The mixture was stirred for $1 \mathrm{~h}$ at room temperature before it was quenched with water and extracted with Ethyl Acetate. The combined organic layers were dried with $\mathrm{MgSO}_{4}$ and concentrated in vacuum. The aldehyde was purified by flash column chromatography (Ethyl Acetate/Cyclohexane 1/8) and the product 5 was yielded $(5.74 \mathrm{~g}, 81 \%) . \mathrm{R}_{\mathrm{f}}=0.57$ (Ethyl Acetate/Cyclohexane, 1:3). [ $]_{D}^{20}=+25.2\left(\mathrm{c} 1.0, \mathrm{CHCl}_{3}\right) \cdot{ }^{1} \mathrm{H} \mathrm{NMR}\left(400 \mathrm{MHz}, \mathrm{CDCl}_{3}\right): \delta=$ $9.54(\mathrm{~s}, 1 \mathrm{H}), 6.37-6.46(\mathrm{~m}, 2 \mathrm{H}), 5.84(\mathrm{~d}, J=18.8 \mathrm{~Hz}, 1 \mathrm{H}), 5.55$ (d, $J=10.0 \mathrm{~Hz}, 1 \mathrm{H}), 5.10$ $(\mathrm{q}, J=7.5 \mathrm{~Hz}, 1 \mathrm{H}), 4.25(\mathrm{t}, J=7.5 \mathrm{~Hz}, 1 \mathrm{H}), 3.76(\mathrm{t}, J=7.5 \mathrm{~Hz}, 1 \mathrm{H}), 1.50(\mathrm{~s}, 3 \mathrm{H}), 1.44(\mathrm{~s}, 3$ H) ppm. ${ }^{13} \mathrm{C}$ NMR $\left(101 \mathrm{MHz}, \mathrm{CDCl}_{3}\right): \delta=193.1,150.0,139.8,126.4,122.9,110.4,72.4$, 
69.0, 26.6, 25.6 ppm. HRMS (ESI): calcd. for $\mathrm{C}_{10} \mathrm{H}_{14} \mathrm{NaO}_{3}[2 \mathrm{M}+\mathrm{Na}]^{+}$387.1778; found 387.1777 .

\section{5. (3E)-Methyl 2-acetoxy-4-((4S)-2,2-dimethyl-1,3-dioxolan-4-yl)-3-ethylidene-6-} methyl-3,4-dihydro-2H-pyran-5-carboxylate (7a): To a solution of aldehyde 5 (200 mg, 1.1 mmol, 1.0 equiv) in DCM (2 mL), R- (+)- $\alpha, \alpha$-diphenyl-2-pyrrolidine methanol trimethylsilyl ether (32.5 mg, $0.11 \mathrm{mmol}, 0.1$ equiv) and benzoic acid (13 mg, $0.11 \mathrm{mmol}, 0.1$ equiv) were added. After $5 \mathrm{~min}$ stirring, methylacetoacetate $(0.12 \mathrm{~mL}, 1.1 \mathrm{mmol}, 1.0$ equiv) was also added to the reaction mixture. After $40 \mathrm{~h}, \mathrm{DCM}(2 \mathrm{~mL})$, acetic anhydride $(0.33 \mathrm{~mL}, 3.3 \mathrm{mmol}$, 3 equiv), triethylamine $(0.21 \mathrm{~mL}, 1.54 \mathrm{mmol}, 1.4$ equiv) and 4-dimethylaminopyridine (13 $\mathrm{mg}, 0.11 \mathrm{mmol}, 0.1$ equiv) were added and stirred for $10 \mathrm{~h}$ at room temperature. The reaction mixture was quenched with water $(20 \mathrm{~mL})$, extracted with $\mathrm{DCM}(3 \times 10 \mathrm{~mL})$, combined organic layers were dried over $\mathrm{MgSO}_{4}$ and solvent was evaporated under reduced pressure. Purification by flash column chromatography (Ethyl acetate/Cyclohexane 15:85) gave the product 7a with traces of impurities in $40 \%$ yield. $\mathrm{R}_{\mathrm{f}}=0.31$ (Ethyl Acetate/Cyclohexane, 1:5). []$_{D}^{20}=-19.4\left(\mathrm{c} 1.0, \mathrm{CHCl}_{3}\right) .{ }^{1} \mathrm{H} \mathrm{NMR}\left(400 \mathrm{MHz}, \mathrm{CDCl}_{3}\right): \delta=6.69(\mathrm{~d}, J=1.8 \mathrm{~Hz}, 1 \mathrm{H}), 5.86-$ $5.75(\mathrm{~m}, 1 \mathrm{H}), 4.11(\mathrm{q}, J=6.2 \mathrm{~Hz}, 1 \mathrm{H}), 3.98-3.88(\mathrm{~m}, 2 \mathrm{H}), 3.72(\mathrm{~s}, 3 \mathrm{H}), 3.71-3.68(\mathrm{~m}, 1 \mathrm{H})$, $2.23(\mathrm{~s}, 3 \mathrm{H}), 2.19(\mathrm{~s}, 3 \mathrm{H}), 1.81-1.75(\mathrm{~m}, 3 \mathrm{H}), 1.37-1.34(\mathrm{~m}, 3 \mathrm{H}), 1.31-1.28(\mathrm{~m}, 3 \mathrm{H}) \mathrm{ppm}$. ${ }^{13} \mathrm{C} \mathrm{NMR}\left(101 \mathrm{MHz}, \mathrm{CDCl}_{3}\right): \delta=169.3,168.2,162.7,130.2,123.0,109.5,103.4,90.6,79.2$, 67.2, 51.5, 36.9, 26.4, 25.7, 21.2, 20.0, 13.8 ppm. HRMS (ESI): calcd. for $\mathrm{C}_{17} \mathrm{H}_{24} \mathrm{NaO}_{7}$ $[\mathrm{M}+\mathrm{Na}]^{+}$363.1420; found 363.1426 .

4.6. (E)-(4S)-4, 5-Dihydroxy-2-vinyl-pent-2-enoic acid methyl ester (9): To a stirred solution of 4 (7.546 g, $35.55 \mathrm{mmol}, 1.0$ equiv) in anhydrous $\mathrm{CH}_{3} \mathrm{CN}$ was added $\mathrm{CuCl}_{2} \cdot 2 \mathrm{H}_{2} \mathrm{O}$ (18.18 g, $106.65 \mathrm{mmol}, 3.0$ equiv) at $0{ }^{\circ} \mathrm{C}$. The mixture was allowed to warm up to room temperature and stirred for $3 \mathrm{~h}$. The reaction mixture was quenched with water $(100 \mathrm{~mL})$ and extracted with dichloromethane $(3 \times 150 \mathrm{~mL})$. The combined organic extracts were washed with brine and dried over $\mathrm{MgSO}_{4}$ and concentrated under vacuum. The desired product 9 was obtained (3.893 g, 64\%) after flash column chromatography (Ethyl Acetate/Cyclohexane 3/2). $\mathrm{R}_{\mathrm{f}}=0.25$ (Ethyl Acetate/Cyclohexane, 1:1). [ $]_{D}^{20}=-14.3$ (c 1.0, $\left.\mathrm{H}_{2} \mathrm{O}\right) .{ }^{1} \mathrm{H}$ NMR $(400 \mathrm{MHz}$, $\left.\mathrm{CDCl}_{3}\right): \delta=6.63-6.51(\mathrm{~m}, J=8.7 \mathrm{~Hz}, 1 \mathrm{H}), 6.44(\mathrm{dd}, J=17.6,11.5 \mathrm{~Hz}, 1 \mathrm{H}), 5.56(\mathrm{dd}, J=$ 17.6, 1.6 Hz, $1 \mathrm{H}), 5.41(\mathrm{dd}, J=11.5,1.6 \mathrm{~Hz}, 1 \mathrm{H}), 4.65(\mathrm{dt}, J=8.6,7.3,3.5 \mathrm{~Hz}, 1 \mathrm{H}), 3.75$ $(\mathrm{s}, 3 \mathrm{H}), 3.65(\mathrm{dd}, J=11.5,3.5 \mathrm{~Hz}, 1 \mathrm{H}), 3.56(\mathrm{dd}, J=11.5,7.3 \mathrm{~Hz}, 1 \mathrm{H}) \mathrm{ppm} .{ }^{13} \mathrm{C} \mathrm{NMR}(101$ $\mathrm{MHz}, \mathrm{CDCl}_{3}$ ): $\delta=167.5,139.7,132.8,128.8,121.4,69.1,65.6,52.3$ ppm. HRMS (ESI): calcd. for $\mathrm{C}_{8} \mathrm{H}_{10} \mathrm{LiO}_{4}[\mathrm{M}+\mathrm{Li}]^{+}$179.0890; found 179.0883. 
4.7. 2-((4S)-(2,2-Dimethyl-1,3-dioxolan-4-yl)methylene)but-3-enoic acid (14): $\mathrm{LiOH}$ (82 $\mathrm{mg}, 33.89 \mathrm{mmol}, 4.5$ equiv) was solubilized in $\mathrm{H}_{2} \mathrm{O}(10 \mathrm{~mL})$ and added dropwise to a solution of 4 (1.60 g, $7.53 \mathrm{mmol}, 1.0$ equiv) in THF (20 mL). Then the reaction mixture was stirred at room temperature for overnight. $\mathrm{HCl}(1 \mathrm{~mol} / \mathrm{L})$ was added to neutralize the reaction until $\mathrm{pH}$ $\sim 3$. The reaction mixture was extracted with dichloromethane $(3 \times 30 \mathrm{~mL})$. The combined organic extracts were washed with brine and dried over $\mathrm{MgSO}_{4}$ and concentrated under vacuo. The desired product 14 was obtained (1.175 g, 78\%) after flash column chromatography (Ethyl Acetate/Cyclohexane 1/2). $\mathrm{R}_{\mathrm{f}}=0.17$ (Ethyl Acetate/Cyclohexane, 1:1). []$_{D}^{20}=+26.4$ (c 1.0, $\left.\mathrm{CHCl}_{3}\right) .{ }^{1} \mathrm{H} \mathrm{NMR}\left(400 \mathrm{MHz}, \mathrm{CDCl}_{3}\right): \delta=10.62(\mathrm{~s}, 1 \mathrm{H}), 6.84(\mathrm{~d}, J=8.3 \mathrm{~Hz}, 1 \mathrm{H})$, 6.50-6.38 (m, $1 \mathrm{H}), 5.52-5.40(\mathrm{~m}, 2 \mathrm{H}), 4.99-4.89(\mathrm{~m}, 1 \mathrm{H}), 4.16(\mathrm{dd}, J=8.3,6.5 \mathrm{~Hz}, 1 \mathrm{H})$, 3.79-3.67 (m, $1 \mathrm{H}), 1.47-1.44(\mathrm{~m}, 3 \mathrm{H}), 1.40$ (s, $3 \mathrm{H}) \mathrm{ppm} .{ }^{13} \mathrm{C} \mathrm{NMR}\left(101 \mathrm{MHz}, \mathrm{CDCl}_{3}\right): \delta=$ 171.6, 141.9, 132.8, 128.7, 122.0, 110.4, 72.6, 69.3, 26.7, 25.2 ppm. HRMS (ESI): calcd. for $\mathrm{C}_{10} \mathrm{H}_{14} \mathrm{NaO}_{4}[\mathrm{M}+\mathrm{Na}]^{+} 221.0790$; found 221.0784.

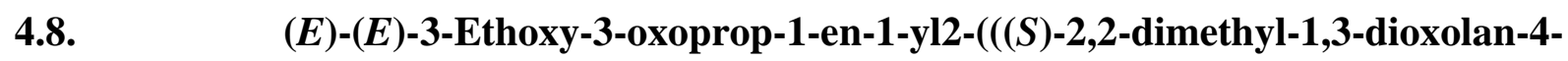
yl)methylene)but-3-enoate (16): To a stirred solution of $\mathbf{1 4}$ (55 mg, $0.28 \mathrm{mmol}, 1.0$ equiv) in acetone was added cyanuric chloride $\left(26 \mathrm{mg}, 0.14 \mathrm{mmol}, 0.5\right.$ equiv) and $\mathrm{Et}_{3} \mathrm{~N}$ (39 $\mu \mathrm{L}, 0.28$ mmol, 1.0 equiv) at room temperature. The mixture was stirred for 3 hours. Acetone was removed under reduced pressure.

A magnetically stirred solution of acid chloride in DCM was cooled to $0{ }^{\circ} \mathrm{C}$ then treated dropwise with Hünig's base followed by intermediate. The reaction was stirred at $0{ }^{\circ} \mathrm{C}$ for $1 \mathrm{~h}$. The reaction mixture was quenched with water $(10 \mathrm{~mL})$ and extracted with dichloromethane $(3 \times 15 \mathrm{~mL})$. The combined organic extracts were washed with brine and dried over $\mathrm{MgSO}_{4}$ and concentrated under vacuum. The desired product 16 was obtained (13.3 mg, 16\% in two steps) after flash column chromatography (Ethyl Acetate/Cyclohexane 1/6); $\mathrm{R}_{\mathrm{f}}=0.55$ (Ethyl Acetate/Cyclohexane, 1:3). []$_{D}^{20}=+15.4\left(\mathrm{c} 0.4, \mathrm{CHCl}_{3}\right) \cdot{ }^{1} \mathrm{H} \mathrm{NMR}\left(400 \mathrm{MHz}, \mathrm{CDCl}_{3}\right): \delta=$ $8.36(\mathrm{~d}, J=12.5 \mathrm{~Hz}, 1 \mathrm{H}), 6.91-6.81(\mathrm{~m}, 1 \mathrm{H}), 6.45(\mathrm{dd}, J=17.4,11.5 \mathrm{~Hz}, 1 \mathrm{H}), 5.81(\mathrm{~d}, J=$ $12.5 \mathrm{~Hz}, 1 \mathrm{H}), 5.61-5.46$ (m, $2 \mathrm{H}), 4.96$ (dd, $J=8.2,6.9 \mathrm{~Hz}, 1 \mathrm{H}), 4.25-4.16$ (m, $3 \mathrm{H}), 3.78-$ $3.70(\mathrm{~m}, 1 \mathrm{H}), 1.48(\mathrm{~d}, J=0.7 \mathrm{~Hz}, 3 \mathrm{H}), 1.42-1.40(\mathrm{~m}, 3 \mathrm{H}), 1.33-1.24(\mathrm{~m}, 3 \mathrm{H}) \mathrm{ppm} .{ }^{13} \mathrm{C}$ NMR (101 MHz, $\left.\mathrm{CDCl}_{3}\right): \delta=166.2,162.0,149.6,143.1,131.4,128.2,122.6,110.6,106.8$, 72.6, 69.3, 60.7, 26.8, 25.8, 14.4 ppm. HRMS (ESI): calcd. for $\mathrm{C}_{15} \mathrm{H}_{20} \mathrm{NaO}_{6}[\mathrm{M}+\mathrm{Na}]^{+}$ 319.1158; found 319.1152 . 
dihydro-2H-pyran-5-carboxylate (17): To a stirred solution of $\mathbf{1 6}(12 \mathrm{mg}, 0.041 \mathrm{mmol}, 1.0$ equiv) in anhydrous THF was added catalyst ( $3.5 \mathrm{mg}, 0.008 \mathrm{mmol}, 0.2$ equiv) and potassium tert-butoxide ( $1 \mathrm{mg}, 0.008 \mathrm{mmol}, 0.2$ equiv) at room temperature. The mixture was stirred for $46 \mathrm{~h}$. The reaction mixture was then evaporated and the desired product $\mathbf{1 7}$ was obtained (7 $\mathrm{mg}, 58 \%$ ) after flash column chromatography (Ethyl Acetate/Cyclohexane 1/6). $\mathrm{R}_{\mathrm{f}}=0.38$ (Ethyl Acetate/Cyclohexane, 1:3). ${ }^{1} \mathrm{H}$ NMR $\left(400 \mathrm{MHz}, \mathrm{CDCl}_{3}\right): \delta=7.62(\mathrm{~d}, J=8.1 \mathrm{~Hz}, 1 \mathrm{H})$, 7.24-7.10 (m, $1 \mathrm{H}$ ), 4.31-4.23 (m, $3 \mathrm{H}$ ), 4.04-4.01 (m, $1 \mathrm{H}), 3.95-3.90$ (m, $1 \mathrm{H}), 3.72-3.67$ (m, $1 \mathrm{H}), 1.96-1.92(\mathrm{~d}, J=7.3 \mathrm{~Hz}, 3 \mathrm{H}), 1.34-1.24(\mathrm{~m}, 9 \mathrm{H}) \mathrm{ppm} .{ }^{13} \mathrm{C}$ NMR $\left(101 \mathrm{MHz}, \mathrm{CDCl}_{3}\right): \delta$ $=165.7,162.7,151.4,145.2,124.6,111.6,109.7,78.7,65.9,61.3,35.6,29.8,26.1,15.3,14.4$ ppm. HRMS (ESI): calcd. for $\mathrm{C}_{15} \mathrm{H}_{20} \mathrm{NaO}_{6}[\mathrm{M}+\mathrm{Na}]^{+} 319.1152$; found 319.1159 .

Supporting Information (see footnote on the first page of this article): Copies of ${ }^{1} \mathrm{H}$ and ${ }^{13} \mathrm{C}$ NMR spectra of all described compounds.

\section{Acknowledgments}

S. W. gratefully acknowledges China Scholarship Council (CSC) for a doctoral scholarship. We thank the University P. et M. Curie and the European Commission for funding of this research through a EMEA Erasmus Mundus Scholarship to J. A. The Fédération de Recherche (FR2769) provided technical access for analysis.

[1] (a) El-Naggar, L. J.; Beal, J. L. J. Nat. Prod. 1980, 43, 649-707. (b) Boros, C. A.; Stermitz, F. R. J. Nat. Prod. 1991, 54, 1173-1246. (c) Dinda, B.; Debnath, S.; Harigaya, Y. Chem. Pharm. Bull. 2009, 57, 765-796.

[2] Trost, B. M.; Mao, M. K. T.; Balkovec, J. M.; Buhlmayer, P. J. Am. Chem. Soc. 1986, 108, 4965-4973.

[3] Inouye, H.; Ueda, S.; Takeda, Y. Chem. Pharm. Bull. 1971, 19, 587-594.

[4] (a) Ohmori, O.; Takayama, H.; Aimi, N. Tetrahedron Lett. 1999, 40, 5039-5042. (b) Wang, C. L.; Liu, J. L.; Liu, Z. L.; Li, X. S.; Cao, X. Y. Chin. Chem. Lett. 2009, 20, 150-152. (c) Yu, Y.; Song, W.; Zhu, C.; Lin, S.; Zhao, F.; Wu, X.; Yue, Z.; Liu, B.; Wang, S.; Yuan, S.; Hou, Q.; Shi, J. J. Nat. Prod. 2011, $74,2151-2160$.

[5] For biological effects of Gentiopicroside see: (a) Tan, R. X.; Wolfender, J. L.; Zhang, L. X.; Ma, W. G.; Fuzzati, N.; Marston, A.; Hosteitmann, K. Phytochem. 1996, 42, 1305-1313. (b) Kakuda, R.; Iijima, T.; Yaoita, Y.; Machida, K.; Kikuchi, M. J. Nat. Prod. 2001, 64, 1574-1575. (c) Chou, C. C.; Pan, S. L.; Teng, C. M.; Gu, J. H. Eur. J. Pharm. Sci. 2003, 19, 403-412. (d) Kumarasamy, Y.; Nahar, L.; Sarker, S. D. Fitoterapia 2003, 74, 151-154. (e) Wang, C. H.; Cheng, X. M.; He, Y. Q.; White, K. N.; Bligh, S. W. A.; Branford-White, C. J.; Wang, Z. T. Arch. Pharm. Res. 2007, 30, 1149-1154. (f) Chen, L.; Liu, J. C.; Zhang, X. N.; Guo, Y. Y.; Xu, Z. H.; Cao, W.; Sun, X. L.; Sun, W. J.; Zhao, M. G. Neuropharmacology 2008, 54, 1175-1181. (g) Chen, G.; Wei, S. H.; Yu, C. Y. Biochem. Syst. Eco. 
2009, 37, 766-771. (h) Mustafayeva, K.; Giorgio, C. D.; Elias, R.; Kerimov, Y.; Ollivier, E.; Méo, M. D. J. Nat. Prod. 2010, 73, 99-103.

[6] (a) Büchi, G.; Carlson, J. A.; Powel Jr., J. E.; Tietze, L. F. J. Am. Chem. Soc. 1970, 92, 2165-2167. (b) Büchi, G.; Carlson, J. A.; Powel Jr., J. E.; Tietze, L. F. J. Am. Chem. Soc. 1973, 95, 540-545.

[7] Laabassi, M.; Grée, R. Tetrahedron Lett. 1988, 29, 611-614.

[8] Liao, C C.; Wei, C P. Tetrahedron Lett. 1989, 30, 2255-2256.

[9] Chang, N. C.; Day, H. M.; Li, W. F. J. Org. Chem. 1989, 54, 4083-4088.

[10] Trost, B. M.; Nanninga, T. N. J. Am. Chem. Soc. 1985, 107, 1293-1299.

[11] (a) Brown, R. T.; Jones, M. F. J. Chem. Soc., Chem. Comm. 1986, 1818-1820. (b) Brown, R. T.; Ford, M.J. Tetrahedron Lett. 1990, 31, 2033-2036.

[12] Tietze, L. F.; Meier, H.; Nutt, H. Liebigs Ann. Chem. 1990, 253-260.

[13] Schreiber, S. L.; Meyers, H. V.; Wiberg, K. B. J. Am. Chem. Soc. 1986, 108, 8274-8277.

[14] Mangion, I. K.; MacMillan, D. W. C. J. Am. Chem. Soc. 2005, 127, 3696-3697.

[15] Garcia, C.; Leon, L. G.; Pungitore, C. R.; Rios-Luci, C.; Daranas, A. H.; Montero, J. C.; Pandellia, A.; Tonn, C. E.; Martin, V. S.; Padron, J. M. Bioorg. Med. Chem. 2010, 18, 2515-2523.

[16] Beckett, J. S.; Beckett, J. D.; Hofferberth, J. E. Org. Lett. 2010, 12, 1408-1411.

[17] (a) Ryan, S. J.; Candish, L.; Lupton D. W. J. Am. Chem. Soc. 2009, 131, 14176-14177. (b) Candish, L.; Lupton, D. W. Org. Lett. 2010, 12, 4836-4839. (c) Candish, L.; Lupton, D. W. Org. Biomol. Chem. 2011, 9, 8182-8189. (d) Ryan, S. J.; Candish, L.; Lupton, D. W. Chem. Soc. Rev. 2013, 42, 4906-4917. (e) see also : Mahatthananchai, J. Bode, J. W. Acc. Chem. Res. 2014, 47, 696-707.

[18] (a) Rueping, M.; Sugiono, E.; Merino, E. Angew. Chem, Int. Ed. 2008, 47, 3046-3049. (b) Rueping, M.; Merino, E.; Sugiono, E. Adv. Synth. Catal. 2008, 350, 2127-2131. (c) Rueping, M.; Sugiono, E.; Merino, E. Chem. Eur. J. 2008, 14, 6329-6332.

[19] (a) Zhu, M. K.; Wei, Q.; Gong, L. Z. Adv. Synth. Catal. 2008, 350, 1281-1285. (b) Yu, C.; Zheng, F.; Ye, H.; Zhong, W. Tetrahedron 2009, 65, 10016-10021.

[20] Lathrop, S. P.; Rovis, T. J. Am. Chem. Soc. 2009, 131, 13628-13630.

[21] (a) Cabrera, S.; Aleman, J.; Bolze, P.; Bertelsen, S.; Jørgensen, K. A. Angew. Chem. Int. Ed. 2008, 47, 121-125. (b) Carlone, A.; Marigo, M.; North, C.; Landa, A.; Jørgensen, K. A. Chem. Comm. 2006, 4928-4930.

[22]Zhong, Y. L.; Shing, T. K. M. J. Org. Chem. 1997, 62, 2622-2624.

[23] (a) Parikh J. R.; Doering W. V. E. J. Am. Soc. Chem. 1967, 89, 5505-5507. (b) Nicolaou, K. C.; Peng, X. S.; Sun, Y. P.; Polet, D.; Zou, B.; Lim, C. S.; Chen, D. Y. K. J. Am. Chem. Soc. 2009, 131, $10587-$ 10597.

[24] Corey, E. J.; Suggs, W. Tetrahedron Lett. 1975, 16, 2647-2650.

[25] Gritter, R. J.; Wallace, T. J. J. Org. Chem. 1959, 24, 1051-1056.

[26] Dess, D. B.; Martin, J. C. J. Org. Chem. 1983, 48, 4155-4156.

[27] For some critical reviews see : (a) Pellissier, H. Tetrahedron 2007, 63, 9267-9331. (b) Bertelsen, S. Jorgensen, K. A. Chem. Soc. Rev. 2009, 38, 2178-2189. c) For some discussions about enamine or iminium activation see: (c) Jørgensen, K. A. Angew. Chem, Int. Ed. 2000, 39, 3558-3588. (d) Jensen, K. L.; Dickmeiss, G.; Jiang, Hao, Albrecht, L.; Jørgensen, K. A. Acc. Chem. Res. 2012, 45, 248-264. 
[28] For a reference on the stereochemical control of conjugated carbon nucleophiles addition to $\gamma$-alkoxy $\alpha, \beta$-unsaturated carbonyl systems see : Kireev, A.S.; Manpadi, M.; Kornienko, A. J. Org. Chem. 2006, 71, 2630-2640 and references cited herein.

[29] Sven M. K.; Martin E. M. Org. Lett. 2002, 4, 643-646.

[30] Bergman, J.; Rehn, S. Tetrahedron 2002, 58, 9179-9185.

[31] Venkataraman K.; Wagle D. R. Tetrahedron Lett. 1979, 32, 3037-3040.

[32] Duhaime, R. M.; Lombardo, D.A.; Skinner, I. A.; Weedon, A. C. J. Org. Chem. 1985, 50, 873-879. 